DOI: $10.2478 /$ ausfm-2020-0010

\title{
Up the Slope. Women's Mobility Stories in Post-Transition Hungarian Cinema
}

\author{
Beja Margitházi \\ Eötvös Loránd University (Budapest, Hungary) \\ E-mail: margithazi.beata@btk.elte.hu
}

\begin{abstract}
Using data and statistics obtained in the research project The Social History of Hungarian Cinema (1931-2015), this study investigates the upward and downward mobility movements of women in the Hungarian films made after the regime change. The political transition following the collapse of communism radically altered the economic and social structure of Hungarian society. The social experiences of losses and failures, as well as the closing social structure are reflected directly and explicitly in many Hungarian films made between 1990 and 2015. With the help of Bernard Weiner's social attribution theory for describing failure and success, the article analyses the narratives of these films in terms of the extent to which and the proportion that they are attributed to inner, individual dispositions or external circumstances. Based on this approach, the author states that female heroines in these movies appear to move "up the slope," as they are pulled down not only by the gravitational force of economic and social crises, but also by the lack of emancipation and gender equality. ${ }^{1}$
\end{abstract}

Keywords: Hungarian cinema, change of regime, social mobility, female protagonists, statistical data analysis.

The end of the communist era did not bring revolutionary changes to the visibility of women in Hungarian cinema, although the emerging new directors and the changed quality of female presence enriched the overall picture with new details. One of the rarely analysed effects of the reorganization of Hungarian film industry after the 1989-1990 regime change was that many more women appeared among filmmakers. Even though their proportion is still very low, over the past thirty years female directors have been involved in many more genre films than before - in addition to the traditionally cultivated auteur films. ${ }^{2}$ Although their increased

1 This work was supported by the Hungarian National Research, Development and Innovation Office (number of Agreement: 116708).

2 The number of female feature film directors has doubled in the post-transition period, partly due to the earlier, but still active generation of directors (Márta Mészáros, Lívia Gyarmathy, Judit 
presence has not influenced the number and frequency of female protagonists compared to previous decades, ${ }^{3}$ some qualitative changes have become more pronounced - for example, in the more prominent female perspective and the trend of multi-protagonist films, ${ }^{4}$ while the majority of contemporary Hungarian films still continue to neglect women's point of view, their problems and difficulties, and their successes and achievements.

Working with data obtained in our research project The Social History of Hungarian Cinema (1931-2015), in this study I examine the social positions and opportunities associated with women in Hungarian films made between 1990 and 2015. In particular, I will focus on women's mobility stories, the rise or fall of women from different social and financial backgrounds, and the way these successes and failures are presented in relation to individual abilities and external circumstances. I assume that the examination of female social mobility sheds a light both on how women are imagined and portrayed in post-transition cinema, and in a more general sense, on the way Hungarian films depict Hungarian society, the overview they offer on the emerging obstacles and opportunities after the change of regime. ${ }^{5}$

In general, it can be stated that contemporary Hungarian film does not idealize regime change, rather it openly reflects on some of the on-going, post-transition social processes - even if this reflection is sometimes highly selective. The deeply rooted tradition of Hungarian auteur film from the 1970s and 1980s to portray downward social and financial movements still persists, although from the 1990s, genre films catch up with the trend of presenting social difficulties (but predominantly

Elek, Ildikó Szabó, Ildikó Enyedi, Krisztina Deák), and the emerging young filmmakers (Ágnes Incze, Ágnes Kocsis, Diána Groó, Krisztina Goda, Anna Faur, Réka Almási, Júlia Szederkényi, Sára Cserhalmi, Virág Zomborácz, Lili Horváth, and most recently Orsi Nagypál and Zsófia Szilágyi). However, the twenty-five female directors still shot only $10 \%$ of post-transition feature films. (For more details see Margitházi 2019, 16.)

3 The average number of 0.6 female protagonists per film was higher only between 1931 and 1945 (0.8, meaning 341 heroines in 396 films). Between 1990 and 2015 there were 274 female protagonists in 448 films; 322 in 514 films between 1964-1989; and 109 in 182 films between 1946-1963.

4 See for example the films of Kocsis, Incze, Enyedi, Goda, Lili Horváth and Zsófia Szilágyi prefer nuanced female characters and perspectives, or the emergence of multi-protagonist films featuring a group of women (friends, relatives or colleagues) as main characters like in Bitches (Csajok, Ildikó Szabó, 1995), Espresso (Presszó, Tamás Sas, 1997), Just Sex and Nothing Else (Csak szex és más semmi, Krisztina Goda, 2005), Girls (Lányok, Anna Faur, 2007), Espresso - 10 years later (Presszó 10 év múlva, Tamás Sas, 2009), Lull (Szélcsend, Tamás Sas, 2009), Singles' Night (Szinglik éjszakája, Tamás Sas, 2010), My Wife, My Woman, My Girl (Nejem, nóm, csajom, Péter Szajki, 2012), Swing (Csaba Fazekas, 2014), Free Entry (Yvonne Kerékgyártó, 2014), etc.

5 In our research we addressed both aspects: about the social image of post-transition films see for example Varga 2016, and about the image of women in Hungarian feature films see Vajdovich 2016 and Margitházi 2019. 
tell social and financial success stories). Compared to male heroes, our research finds that after the regime change female protagonists have become more active indicators of social transformations. Social decline and financial success are two types of alterations that are especially often associated with women, although these never appear together. In this article I will argue that Hungarian films paint a pessimistic picture of post-transitional social changes through female protagonists, emphasizing social difficulties and hopelessness in stories of decline, and revealing the lack of emancipation in stories of success - which often represent women as being dependent on men. Using Bernard Weiner's social attribution theory for describing failure and success (Weiner 2012), I will analyse the nature of these changes in terms of the extent to which and the proportion that they are attributed to inner, individual dispositions or external circumstances.

The situation of women can thus be studied in the context of the 1989-1990 regime change, which despite its diverse and contradictory impacts, can be considered a turning point triggering economic, political and social transformation. In the followings I will briefly summarize the impact of Hungarian regime change on social mobility, and review the portrayal of women in the context of their class and financial status, to finally address the particularities of women's mobility stories through brief plot analyses and comparison of situations, conflicts, causes and motivations.

\section{Regime Change and Social Mobility}

The peaceful transition from (state) socialism to capitalism in the entire Eastern European region came at a much higher social and economic price than imagined. In Hungary, the inherited difficulties of the strongly centralized planned economy of the Kádár era were accompanied by the jolt of Eastern European regime changes coinciding with the acceleration of globalization mechanisms. Thus, the Hungarian society transitioning to a market economy faced several challenges for which it was not prepared; as a result of these, the first crisis in the 1990s was quite predictable.

While the essence of political transitions (from party-based dictatorship to parliamentary democracy) and market transformations (from planned economy to market economy) can be clearly and accurately described, social changes show a much more complicated overall picture (Valuch 2015, 21). The post-communist society has become significantly more stratified than before; as a result of the changes in regionality, income, education, occupation, and participation in the private economy, a highly polarized, fragmented and markedly disintegrating 
society has emerged, which stood in sharp contrast with the imagined "balanced, modern society capable of creating and maintaining the long-awaited, desired wellbeing" (Valuch 2015, 15).

Social mobility, in the original sociological sense, refers to the various changes in status whereby individuals and families move between social classes and strata (Andorka 2006, 233). Mobility opportunities reflect the dynamics of social structure, provide insights into the chances of social openness, the opportunities of advancement, and the possibilities of retaining acquired positions in a given age and political system, and thus are comparable to data from previous eras (Bukodi 2002 , 193). This makes visible what social movements the respective system allows, how it changes the stratification and to what extent it provides similar leeway for those belonging to different groups; in other words how open and closed the social structure is. Modern mobility research defines mobility not only as a change in class and property status, but in several other categories, like occupation, income, education, place of residence, lifestyle, esteem and prestige (Andorka 2006, 233). In addition to vertical movement in the social hierarchy, mobility can also be horizontal (e.g. change of occupation within the same property and class situation), and it can also stagnate if the status of the participants shows permanence. In addition to intragenerational changes (achieved in a person's lifetime), sociologists examine intergenerational mobility in large samples, comparing statistics from fathers and sons; they also distinguish between objective and subjective mobilization, which refers to real and perceived status change, and the degree of satisfaction with it. ${ }^{6}$ The mobility study may also shed light on gender differences in mobility opportunities, highly affected for example by family formation. ${ }^{7}$

After the change of regime, the stratification of Hungarian society, and the size and composition of the individual groups began to change gradually, partly following the processes that started in the last decade of the Kádár era. The political transition between 1990 and 1995 was accompanied by a painful transformation of market conditions, a slowing economic development and a sudden increase of unemployment, which affected many. As usual at the beginning of a new era, the structure of society became more open and mobility increased (Róbert and Bukodi 2004, 287-288). Hungarian society became more heterogeneous, the elite transformed, the middle class became smaller and the lower middle class increased

6 On the subjective mobility in relation to Hungarian regime change see Róbert 1999, or recently Huszár and Záhonyi 2018.

7 See, for example, differences in education, employment and career development, or the case of marital mobility, which refers to changes in the social situation of people of different backgrounds through marriage (Andorka 2006, 234). 
(Valuch 2015, 99), while the proletarian, marginalized urban and rural people formed an increasingly significant part of the Hungarian society of the 1990s - that is, most of the mobility movements were downward (Róbert and Bukodi 2004, 292).

The period between 1996 and 2002 brought about a consolidation of the rearrangements. By the turn of the millennium it became clear that the change of regime meant an ascent for some and a descent for others; social groups and mobility opportunities had become more closed by this time, as "entry and exit required more and more effort" (Valuch 2015, 99). The vertical mobility of men had slowed or even reversed, but that of women had also deteriorated (Németh 2006, 23), if not to the same extent as that of men (Róbert and Bukodi 2004, 311). At the beginning of the 2000s, European integration and temporary economic consolidation were followed by a crisis (2008). As a result, the embourgeoisement process of the formation of a stronger middle class did not materialize for the 2010s as it was expected. Drastic differences have developed between metropolitan, small-town and rural groups, and due to their weight and proportion, the lower social strata has become more and more dominant. ${ }^{8}$ In the wake of the processes that started with the change of regime, by the 2010s "mobility opportunities have become largely one-way: it has become easy to move down one layer, but virtually impossible to step back or move to a higher social status" (Valuch 2015, 123).

\section{Women, Protagonists, Data}

Socially relevant statistics of feature films offer new perspectives in studying women's portrayal, but also raise a series of methodological questions. Based on the analysis of narratives and characters, previous literature on female figures of Hungarian films either undertook a more comprehensive, historical, sociological examination of certain films of a period (Szilágyi 1983; Szilágyi 1985; Varga and Kresalek 1995; Gyarmati 2004; Schadt 2012), or critically analysed some films according to a given paradigm of cultural theory (Hollós 2000; Havas 2010; Havas 2011; Király 2018). This was occasionally complemented by the context of production as well as the perspective of female creators (Hock 2007; Hock 2010; Virginás et al. 2018), while neither approach used statistics or systematically collected big data about films.

One of the key features of the data on women explored in our research was the quantity and frequency of female protagonists. In relation to the gender of protagonists

8 Tibor Valuch is quoting here the data of the social structure also referred to as the "pear," published in the summary of the survey Osztálylétszám 2014 [Class Headcount 2014] conducted by MTA TK and the GfK Market Research Institute (Valuch 2015, 123). 
and the number of films, it can be clearly seen that the number of male protagonists always exceeds the number of films in any given year, whereas the number of female protagonists is typically below that (see Figure 1 in Vajdovich's article in this issue, vol. 18 of Acta Universitatis Sapientiae, Film and Media Studies) - which means that most Hungarian films have fewer female protagonists than male ones, or none at all. ${ }^{9}$ This trend shows somewhat varying proportions from era to era, but has been moving along similar parameters since the late 1940s. After the regime change, the number of male protagonists and the number of films sometimes align, the number of men sometimes even falls below the number of films (see 1994), while that of female protagonists, with one exception (2012), falls short of both. ${ }^{10}$

Of course, besides the quantity of protagonists, the quality of their presence may also vary. Even if female protagonists appear, the way in which they are presented will be dependent on the storytelling techniques - in terms of whether the perspective or opinion of the woman really counts, whether her character is nuanced, whether her thoughts and feelings are revealed, and whether her real problems are given space. In genres dealing with love ties (e.g. melodrama, romantic comedy), it is particularly common for both members of the couple to appear as protagonists due to the action-shaping significance of the heterosexual relationship, yet the narration adjusts its point of view to the male protagonist. ${ }^{11}$ This also affects the mobility stories discussed here: women sometimes appear on the side of men as associated protagonists, in that they only have a secondary role in the narrative (like e.g. in Noah’s Ark [Noé bárkája, Pál Sándor, 2007], Feri and Sweet Life [Feri és az édes élet, György Czabán, 2001], Bakkerman [András Szőke, 2008]), while in several other cases they appear as absolute protagonists (e.g. The Rapture of Deceit [A csalás

9 The 1509 films in the database feature a total of 4452 male and 2573 female characters, of which $43 \%$ and $44 \%$ are protagonists (1946 men and 1101 women), respectively. This proportion seems to be valid not only for Hungarian films. Janet Thumim, for example, found similar relations when examining female protagonists in British popular films: the ratio of male and female protagonists in the most popular and profitable movies of the forties, fifties and sixties is $2: 1$, but there appeared also more men than women in the supporting roles, or in the streets and other mass scenes (Thumim 1992, 86-88).

10 For a brief overview of the proportions of female and male protagonists in the different eras see Vajdovich 2019, 10.

11 In the love stories of contemporary romantic comedies, for example, both members of the couple may appear as protagonists, but the narrative is rarely double-focalized; while in some cases we can follow the vicissitudes of matchmaking from the perspective of the female protagonist (e.g. Stop Mom Theresa! [Állítsátok meg Terézanyut, Péter Bergendy, 2004], Just Sex and Nothing Else, Singles' Night or Liza, the Fox-Fairy), in several other cases we follow the plot through the struggles and problems of the male character (e.g. Pizzaman [Pizzás, György Balogh, 2001], SOS Love [SOS szerelem, Tamás Sas, 2007], 9 and Half Dates [9 és fél randi, Tamás Sas, 2008], Poligamy [Dénes Orosz, 2009], Coming out [Dénes Orosz, 2013], What Ever Happened to Timi [Megdönteni Hajnal Tímeát, Attila Herczeg, 2014]). 
gyönyöre, Lívia Gyarmathy, 1992], Dear Emma, Sweet Böbe [Édes Emma, drága Böbe, István Szabó, 1992], Virtually a Virgin [Majdnem szûz, Péter Bacsó, 2008], All is Casting [Casting minden, Péter Tímár, 2008], Swing [Csaba Fazekas, 2014] or Liza, the Fox-Fairy [Liza, a rókatündér, Károly Ujj Mészáros, 2015]), thus, the reasons and motivations that drive their actions are also more transparent.

The adult, ${ }^{12}$ middle-class, middle-income woman is overrepresented among the female protagonists after the change of regime, as in Hungarian films in general, but beyond that, women's social and wealth status varies widely. The comparison of the social stratum of male and female protagonists [Figs. 1 and 2] shows the regular and continuous presence of the lower and middle classes for both sexes after 1990: with one exception (women, 1999), these two classes are continuously present in Hungarian feature films, although the large number of middle-class protagonists is not fully in line with the actual social stratification trends of the period, which point towards a slimmer middle class and a gradual increase of the lower strata. ${ }^{13}$ There is a gender gap for upper-class protagonists: while we find an almost equal number of upper middle-class men and women, the class at the top of the hierarchy is represented more often by male than female protagonists; while upper-class female protagonists appear only in certain years (for a total of seven years), for male protagonists this seems to be a more typical status (absent for a total of eleven years).

The financial position shows a more nuanced picture and more gender differences [Figs. 3 and 4]. The number of protagonists with average wealth is by far the highest for both sexes, but while poverty appears associated recurrently with male characters (with the exception of 2012), poor female protagonists are missing for several years (1989, 1995, 1997, 2002, 2012). However, extreme poverty - almost totally underrepresented throughout Hungarian film history - is more often associated with female actors (see 1999, 1992, 2007, 2008 and 2012) than with men (2012). The wealthy status, indicating the best financial situation, typically soars after the 2000s for both sexes, but in total it is associated more often and more persistently with men than women. While the wealthy woman appears as a characteristic category of posttransitional Hungarian film, the class and wealth positions of female protagonists broadly follow the trends of men; however, significant exceptions appear at the two endpoints of the social spectrum: women are more absent from the upper classes and are more present among the poorest, which suggests unequal power relations and a subordinate position of women.

12827 adults, 191 young women, 31 children and 49 old women.

13 The stratification of Hungarian society after the change of regime has been researched and described according to several methods and concepts, some of them different from the ones we apply, thus the results are often not convertible into the categories used in our research. 


\section{Characteristics of Female Social Mobility}

The social mobility of characters is reported in the "changes" category of our database, which records the major changes in status experienced during the plot, from the beginning to the end of the story. Some of these are changes in wealth (financial success, enrichment; financial decline, bankruptcy), social status (social ascension; social decline), other changes in status (recognition, success; moral downfall; character development; death) or an absence of change altogether (no change; no information). We measured upward mobility by the positive changes in wealth and social status (financial success and social ascension), and downward mobility by summing their negative counterparts (financial bankruptcy, social decline). These character-related changes appear in the movies in different configurations, as a character can be associated with several different types of change within a category. In the calculations we took into account the occurrence of the given types of changes, regardless of the context and other associated change types.

Viewed from a chronological perspective, we have found that after 1989 [Figs. 5 and 6], the category of social decline reaches the highest, most extreme values for both sexes, but while for men it peaked earlier, in the late 1960s and then in the last half of the 1990s (30\%), in the case of female protagonists this took place in the early $1990 \mathrm{~s}$ $(58 \%)$ and then in the mid-2000s (above $40 \%$ ), and to an even greater extent than in the case of men. Despite fewer female protagonists, financial decline is also much more common among women at the "low point" of the early 1990s, when the occurrence of it rises, along with social decline - although material success is also associated with women more often and in greater numbers in the mid- and late 2000s. This follows the general upward and downward social and financial tendencies described in Hungarian society in these decades (Valuch 2015; Róbert and Bukodi 2004). Social ascension reaches its highest values at different periods in the case of the two sexes: we see the highest values between 1993 and 1997 for men and between 2006 and 2009 for women. Financial success, on the other hand, has shown the highest values for both sexes only since the second half of the 2000s, and it is also clear that the lack of change ("no change" category) is more common among male actors.

If viewed in proportions [Fig. 7], data aggregation shows that financial decline was the only mobility factor that was present to a similar extent for both male and female protagonists before and after the change of regime (5-6\% of all types of change). Of the four aspects examined, however, the most common category, social decline develops differently for the two sexes: it increases in the case of women by about the same amount that it decreases in that of men (4\%). At the same time, the occurrence 
of financial success increased for both sexes - but much more significantly for women (from $1 \%$ to $6 \%$ ) than for men (from $5 \%$ to $6 \%$ ). The incidence of social ascension is just the opposite: it varies little for women (from $3 \%$ to $4 \%$ ) and decreases significantly for men (from $9 \%$ to $4 \%$ ). The category of "no change" (i.e. characters who do not show any type of change) does not necessarily mean neutrality; whereas the presence of this type of change is exclusive to a given character, the large number of examples may display a general condition of immobility and stagnation - this aspect is unchanged for women (remains around 30\% before and after the change of regime), but increases by $10 \%$ for male protagonists.

In summary, therefore, for women, a positive and a negative mobility value, financial success and social decline are most common in post-transition films, while for men, the values of both social decline and ascension come to a halt, which is, on the other hand, confirmed by the significant numerical increase in the category recording the absence of any changes. Based on the data, it seems that the mobility movements of female protagonists better embody and embrace the real, ongoing upward and downward mobility fluctuations experienced by society after the regime change, while the values of men much rather reflect immobility, the narrowing opportunities, and the closure of the social structure. With the data grouped from a different perspective, it becomes clear that the thing the regime change affected most dramatically is the distribution and polarization between genre and auteur films of women's success and failure stories [Fig. 8]. In the period between 1964 and 1989, stories of women's downward mobility were clearly the preserve of auteur films, wherein the value of social decline is particularly high, with there being almost no examples of upward mobility (financial success or social ascension). In contrast, social ascension is somewhat more common in genre films - a level to which the values of social decline are closer. In the two and a half decades after the regime change, this will change drastically: while the preference of auteur films for social (and financial) decline stories remains unchanged, genre films evolve a lot in terms of both number and types of mobility displayed: social decline is an absolute leading value here as well, but is immediately followed by financial success, then financial decline, then social ascension. All this, then, indicates two parallel processes: on the one hand, popular genres are becoming more common ${ }^{14}$ and on the other, the represented social changes are becoming more diverse. The number of examples of

14 After the change of regime the number of auteur films gradually decreased, while the number of genre films increased. In the 1970s (1970-1979) 68\% of films (137 out of 202 films), and in the 1980s $72 \%$ of the movies (145 out of 201) were auteur films, by the 1990s this proportion had fallen to $45 \%$ ( 77 out of 171 films). By the middle of the 2000 s the proportion of auteur films falls to $38 \%$ (112 out of 297 films between 2000 and 2015). 
upward and downward mobility is increasing, thus, by giving a balanced spectrum of social changes, genre films seem to give a more complete picture of the changes taking place in Hungarian society.

In moving to a closer analysis of why and how the successes and failures are motivated, I review these narratives with the help of Bernard Weiner's attribution theory (Weiner 2011). In this model, Weiner classified the causes associated with individual successes or failures along three dimensions (see an interpretation of Weiner's categories in Fig. 9): according to the locus (external or internal origin), the stability (permanent or occasional, temporary), and the controllability of the causes (Csepeli 1997, 254-255). Internal, personal causes can be long-term (talent, ability) or occasional (efforts, mood), just as external causes can be stable (social, economic circumstances) or occasional (luck, chance). In this system the only controllable element for the individual is the internal, occasional factor (effort), while the other three factors act regardless of the person; specifically, external, permanent (circumstances) causes are most inherently related to the social context. By this, the social references of the films become identifiable, as in most mobility stories a distinction can be made between situational or distributional attribution. In the following, I review the stories of women's financial and then social ascension, and afterwards the narratives of social, then financial decline, and reflect on the causes of these mobilities.

\section{Financial Successes: Inheritance, Prizes, Talent and Self-Reliance}

While the narratives of success, i.e. the stories of social ascension and material prosperity were thematized in half of the films in the period between 1931 and $1944,{ }^{15}$ after 1989 we find far fewer examples of upward mobility for both sexes. In this era there are no overlaps between upward and downward mobility values in the case of female protagonists, only within categories: financial success and social ascension may go hand in hand, just as values of decline may appear together at times, but we see no example of intersections (ascension with decline). Although we have not taken it into account here that the category of "moral downfall" often accompanies enrichment.

Financial success associated with women occurs typically only in the 2000s and exclusively in genre films: mainly in comedies and crime films -in the case of the latter it is always paired with moral downfall (Konyec, [Gábor Rohonyi, 2006],

$1552 \%$ of the feature films of the era (183 out of 354 films) presented stories of upward mobility, while downward mobility appeared in only $18 \%$ of the movies (Lakatos 2018, 12). 
Nosedive [Zuhanórepülés, Erik Novák, 2007], Deathwaltz [Halálkeringó, Károly Krisztián Köves, 2010]). According to the moral of these stories, women do not get rich as a result of practising their profession or through hard work, but rather as a reward for their skills and perseverance; internal, permanent and occasional causes are sometimes accompanied by external, occasional causes (luck), and the origin of money is typically gambling, lottery winnings, cash prizes or inheritances, and in stories of financial decline, bank robbery or drug dealing.

Blind chance alone plays a role in only one film: in Feri and Sweet Life (2001) the title character's wife, Joli, who is in her fifties, unexpectedly wins the lottery. György Czabán's film simultaneously reflects on the everyday working-class life conditions (housing estate, second jobs, weekend fishing) and the nouveau riche accessories (luxurious villa, alternative medicine, love adventures, etc.), and shows the process by which ordinary workers try and fail to adapt to an elite lifestyle. The moral of the story would be that sudden upward mobility through financial success raises conflicts, leads to disintegrating relationships and does not bring the desired happiness. Three other female protagonists also expect inheritance, but wealth brings moral dilemmas with it. In the story of Point of Return - Transylvania 1990 (Ennyiból ennyi, Gyula Maár, 2000), which is set in the nineties, Klára Szapolyai wants to occupy a Transylvanian village mansion by pretending to be the baronial heiress of the neglected castle. Village life, and specifically the local entrepreneur and the engineer's conflict reflects on the new conditions after the collapse of communism - with the rearrangement of power positions and redistribution of goods. Klára seems to be a smart swindler: although there are several indications that she has nothing to do with the former baronial family, using her attractiveness she skilfully wins the engineer over to finally take control.

Money does not help, and there is no release from past sins of the family members in Köves's crime film, Deathwaltz (2010). Elza, a pregnant policewoman in her thirties, is party to a love triangle between her policeman husband and his criminal friend, in a situation that is both morally and financially compromising. The unexpected visit of Elza's long unseen father brings her the opportunity for a new beginning: the former detective father tries to save her by removing all the criminal evidence against her. He even sells his house to leave his entire fortune to his daughter, but only Elza's new-born child survives the shooting at the end of the film.

Inheritance appears as a reward for deserving work in the romantic comedy Liza, the Fox-Fairy, in which a lonely maid cares for the widow of a Japanese ambassador for several years; the widow in her will leaves the apartment to the modest servant instead of her money-grabbing relatives. But in the surreal-fantastic story the 
inherited apartment itself does not bring happiness for Liza, as she has to defeat an evil demon and survive the torments of matchmaking and dating.

In another group of films, female protagonists have specific individual or community goals, for which they earn money in the form of prizes or cash rewards, through ingenuity, perseverance, and some luck. In Sándor Pál's Noah's Ark Ede Stock persuades his granddaughter, Kati, to participate in a commercial TV contest for the best grandfather in the country: if they win the five-million-forint grand prize, he could buy his longed-for Harley Davidson motorcycle. The partying, rebellious Kati is more of a sometimes dynamizing, sometimes obstructive side character in her grandfather's plot, and in the end she only benefits indirectly from the prize.

In addition to talent and perseverance, the teacher heroes of Gábor Fisher's comedy, Montecarlo! (2004) also need luck to win the money that is needed to save the school. The noble community goal ironically tells of the lack of funding for education, and the intellectual heroes forced to convert their professional knowledge to gambling. The French teacher, Annamari will be a key figure in this process: although the money won on gambling in Montecarlo can be attributed to her colleague's magical intuitions, she is able to finally attain the prize by joining a French player.

Jutka, the engineer protagonist of The Rapture of Deceit (1992) receives a big sum of money as a reward. In the chaotic years after the change of regime, her husband, in the hope of a better career, goes off with his boss' daughter. Jutka loses her job and apartment, and so needs to work as a waitress. At the bistro she finds herself in the middle of a restaurant mafia clash; since she does not lose her cold blood and perseverance, her boss rewards her loyalty with a substantial sum of money. The artificial happy ending of Livia Gyarmathy's drama suggests that even if the money is "dirty," it rewards the loyalty and trust of an innocent person, giving her back the chance of starting a new life in her own home, independently and freely.

These stories attribute higher importance to situational considerations than the heroines' own efforts or skills. We rarely find autonomous female protagonists who work hard for financial success and independence, whereby their ascension clearly has permanent and occasional dispositional motivations, like talent and efforts. In some of the exceptions, like Péter Bacsó's farce But Who are those Lumnizter Sisters? (De kik azok a Lumnitzer nóvérek?, 2005) the world of restaurants appears to be a man's world; the only woman amongst the protagonists, Milica, is an atypical character, employed as a detective and bodyguard. She investigates the mysterious restaurant critics on behalf of her corrupt boss, until she finally falls in love with one of them. Even if her upward mobility is ensured by the comedy's 
happy ending, she acts as an independent and successful woman, able to resolve the conflicts around her: after resigning from her job she buys up the newspaper where the gastronomy experts will be allowed to write their free-spoken reviews. Bacsó's other drama emphasizes the role of education and learning in upward mobility. In Virtually a Virgin (2008), Boróka Árva, who grew up in an orphanage, experiences the most significant journey of ascension in these movies: beginning her adult life as a prostitute she finally becomes an advertising expert, partly because of her resilience and partly due to the support of her boyfriend; then she not only succeeds in her newly acquired profession, but even teaches her former clients and pimp a lesson.

The films after 2000 reflect on the growing role of media, advertising and entertainment industries in daily life. The road to financial success leads through show business for the female protagonists of two musical comedies, which typically emphasize not only talent, but the combined power of casual, external circumstances, relationships and luck. In Péter Tímár's All is Casting, the Roma Kati Ormos is the heroine of a mobility story sprinkled with folk tale elements: she becomes a nationally known singer by winning a TV talent competition, which not only requires endless perseverance from her, but also appropriate supporters (teacher, Dadus). In Csaba Fazekas's Swing, three women of different ages and backgrounds begin their singing careers in a summer roadshow with the support of a former diva. The narrative successfully weaves together the differences between the characters' talent and their ideas about success: Kati, the single mother, needs money; Rita, who broke up with her wealthy, unfaithful husband, needs time and distance; Angela, the beginner singer, who left her kindergarten job, needs independence and opportunity to break out. Swing's story about individual accomplishments and female collaboration points out the importance of adapting and learning, but it is also clear that success would not be attainable without patrons and connections.

\section{Social Ascension with Male Help}

Social ascension of female characters after 1990 appears in dramas and comedies, rarely in auteur films, and often, but not in all cases, accompanies financial success - like in Virtually a Virgin, All is Casting and The Rapture of Deceit. But while financial success could be achieved by women on the basis of their abilities, social ascension, according to the lessons of the films, is much more likely to be possible on the side of men. Marital mobility was a typical upward mobilization path in 
Hungarian films before $1945 ;{ }^{16}$ after the change of regime, marriage is not the only reason for, and is not a guarantee of a change in social status, but a relationship, or male company accelerates the process in several films.

In the grotesque-surreal, fairy-tale-like world of Liza, the Fox-Fairy the inherited apartment does not automatically move Liza up the social ladder; her ascension is fulfilled after her marriage to the detective, when she becomes a modern wife, travelling every year to a different place for vacation with her family.

In another comedy, Bakkerman, the female hero does not see any trajectory of upward mobility in her village community, the members of which are portrayed as a group of bumbling losers. The villagers prepare to bake the biggest bread in the world to rescue the small local school, but their plan is already hampered by the collapse of the oven built of stolen bricks. In the meantime, the unemployed teacher, Tündike, after some hesitation, chooses to accept the offer of a star-maker manager who travels through the village, and goes with him in the hope of a better future. The growing chaos and the rearrangement of social structures seem to favour the advancement of female protagonists.

In Werckmeister Harmonies (Werckmeister harmóniák, Béla Tarr, 2000), one of the rare auteur films presenting female social ascension, Tünde, the former wife of an old musicologist, Mr. Eszter, gets actively involved in controlling riots on the streets; the men listen to her word, and together with her new partner, the police captain, she initiates strategic decisions on how to calm down the enraged mass.

Marital mobility is somewhat reversed in the western woman-eastern man pair of Bolse Vita (Ibolya Fekete, 1996), where the main character, Maggie, visits Budapest out of a desire for adventure; there she meets and then marries the Russian musician Jura, with whom she travels back to England, from a chaotic Hungarian capital that is beset with the turmoil of the regime change.

\section{Social Decline: External Circumstances and Emotions}

Social decline is the most common mobility process assigned to women in Hungarian films after the change of regime. In many cases it appears as a single factor, but it may be accompanied by character improvement or financial decline, and less often by moral downfall or death. If women's success stories regularly emphasized the

16 Györgyi Vajdovich calls "love-career-stories" those films made between 1931 and 1945 in which women reach better financial status and/or a higher social position through marriage (Vajdovich 2016, 9). In this era, half of the success narratives of comedies (52\% of 109 films) are characterized by this type of mobility, mostly associated with women ( $69 \%$ of the cases), but it is not uncommon in male protagonists either (Lakatos 2018, 13). 
role of disposition (individual abilities), in most of the decline stories situational factors (external causes, circumstances) are responsible for showing a gloomy overall picture, filled with stagnation or deterioration. Individual competencies here do not even get the chance of being revealed, or are doomed to failure from the outset, as can be seen in most of the auteur films involved. These situational factors causing the decline have in many cases a political and ideological origin, and the heroines, as victims of the circumstances, slide helplessly lower and lower. In the case of some of the historical films, this is linked to traumatic events of the first half of the twentieth century, such as the Holocaust, the Stalinist cleanings, or the revolution of $1956 .{ }^{17}$ The protagonists of these auteur films offer a contemplative and observational female perspective on these historical events, in which they are unable to act, or unable to confront the incidents. In Why Wasn't He There? (Senkiföldje, András Jeles, 1993), Eva as a little girl watches and documents in her diary the deportation of Jewish families in a small town, until finally her family has to go too. In Little Vilma - The Last Diary (Kisvilma - Az utolsó napló, 1999), Márta Mészáros reconstructs the title character's story from the perspective of her adult self returning to a Kyrgyz camp, recalling the process of losing her parents and then the years spent in an orphanage. The condition of the protagonists of two other stories, which are set closer to the present, is similarly vulnerable and hopeless. Based on the short story by Ádám Bodor, The Outpost (A részleg, Péter Gothár, 1994) is set "somewhere in Eastern Europe" in the eighties; the faceless higher office awards the white-collar protagonist, Gizella Weisz a mission, in which she finally loses everything she had. She endures with dignity the exile to the end of the world, in a mountain hut, but the film leaves no doubt that this is an irreversible decline story in which the protagonist's opportunities for action are utterly narrowed. Similarly, Mária, the heroine of the crime film Death in Shallow Water (Halál sekély vízben, Imre Gyöngyössy and Barna Kabay, 1994), which is set in the early nineties, is helpless against the systemic oppression: first her inventor husband and then her student son were drowned in the river by KGB agents, as a result of reports filed by informers. Mária vainly attempts to confront their former friend with the consequences of his actions, whereupon the man, who has meanwhile acted as the hero of the regime change, routinely breaks her down and calls an ambulance to take her away.

17 In films commemorating the 1956 revolution, female protagonists, drifting with the events, gradually lose everything, whether as mothers (like Teréz in Rosehill [Rózsadomb, Mari Cantu, 2003], Mrs. Mansfeld in Mansfeld [Andor Szilágyi, 2006]), or as the love-interests of young male protagonists (e.g. Viki Falk in Children of Glory [Szabadság, szerelem, Krisztina Goda, 2006] or Júlia in 56 Drops of Blood [56 csepp vér, Attila Bokor, 2007]). 
In the set of decline stories that make up the largest group, heroines actively fight to survive, so as to move out from the periphery or from their disadvantaged situation, however not only is the outbreak impossible, but they often slide even further down the slope. In the process of decline men often show up as downward mobility factors, either as representatives of power or as love interests. In one of the two non-synchronous films, Opium - Diary of a Madwoman (Ópium - Egy elmebeteg nô naplója, János Szász, 2007) a strange young graphomaniac girl, Gizella Klein, becomes a patient of the sex maniac, morphine-addicted psychoanalyst and writer, Dr. Brenner. In Szász's auteur film the doctor is struggling with a creative crisis, while his patient is suffering from the consequences of a serious mental illness; the two start a relationship, which is difficult to hide in the closed institution. Finally Gizella is the one who will lose everything: understanding that she will never be able to be healed, she asks Brenner to perform a lobotomy on her before he leaves the hospital for good. In Péter Bacsó's drama, Stalin’s Bride (Sztálin menyasszonya, 1990) mental illness similarly indicates downfall. In a Soviet village in the 1930s people don't know how to treat Paranya, the mentally disturbed, strangely behaving heroine, so sometimes they help and sometimes they abuse her. Fed up with the emotional manipulation and threatening mood of terror, Zorka, a villager, finally kills the tormented woman, who is eventually endowed with a strange power.

The majority of women's failure stories take place in Hungary after the change of regime and are told in auteur films. The two young Russian teachers of István Szabó's Sweet Emma, Dear Böbe had moved from the countryside years before the change of regime in the hope of a better life; after the change their knowledge suddenly proves to be unnecessary, and their desperate survival strategies prove hopeless in the Budapest of the nineties. Tucked away at a teacher's hostel, they take English language courses, look for work and love, but neither Emma (who becomes the lover of the opportunist schoolmaster), nor the more uninhibited Böbe (who eventually goes to prison for prostitution and illegal currency transactions) can find happiness. Although Emma finally enters into a new relationship, the hopelessness of their situation is strongly emphasized by Böbe's decline, and Emma is unable to stop her girlfriend from committing suicide. In György Szomjas's grotesque and tragicomic Junk Movie (Roncsfilm, 1992), set right in the year of the regime change, everybody gets by in the closed, chaotic world of a dirty, run-down pub and block of flats of Budapest's eighth district, but it is redundant to contemplate any kind of mobility. Men and women are equal and their actions are unwarrantable: Gizi Sánta throws out her tenant and welcomes a new man into her apartment, but nothing can bring about a groundbreaking change in the everyday lives of the petty 
people wallowing in physical violence, misfortune and alcohol intoxication. For the heroines of Bloodline (Vérvonal, Pál Erdőss, 1993) and Passport (Paszport - Útlevél a semmibe, Péter Gothár, 2001), which are set in the countryside, there is no way out of deep, chronic poverty. The (half) orphaned teenage girls in Erdőss's film, after an unsuccessful suicide, escape from an educational institution and visit the alcoholic father of one of them. On a farm in the middle of nowhere, in accordance with the girls' plan, Marianna seduces Marilyn's father as form of revenge; the pregnant girl and her girlfriend escape from the torched farm to start a new life and to raise the unborn child, which is particularly disturbing in the light of these terrible events. In Gothár's film, Jelizaveta, who is toiling in a brick factory at Beregszász, will be the wife of her distant relative, Jóska, a seriously alcoholic farmer who has been left behind by his father and sister. The conformist and optimistic Jelizaveta gladly moves to Hungary and gives birth to a little girl for Jóska, but finally comes to realize that he is a violent man who destroys everything and everyone around her. The woman flees, leaving her apartment and existence behind, but her sufferings persist, as she almost loses her daughter, and she cannot hope to get help from the law.

Csaba Bollók's 2007 film also sets its story in a peripheral region (the valley of the river Jiu in Romania) that is sunk into deep poverty, where the title character of Iska's Journey (Iszka utazása) collects metal around the mines, and brings all the money home to her alcoholic and violent parents. The little girl, who has been abused several times by her mother, slips even further into decline at the end of the film: on one of her wanderings she is kidnapped by traffickers and sold as a child prostitute.

Another group of characters find themselves in a vulnerable position for dispositional reasons, sometimes as a result of a wrong decision made at the wrong moment - such as the divorced math teacher, Galina in Homo novus (Pál Erdőss, 1990). In helpless rage, Galina hits one of her speech-impaired teenage students - this unleashes the fury of the small town, which sweeps her and her son away. Hanna Szendrőy, the elderly, middle-class protagonist of The Eighth Day of the Week (A hét nyolcadik napja, Judit Elek, 2006), was once a successful prima donna, now she lives in her garden villa in Buda, but soon she finds herself among the homeless people of the Eastern Railway Station because she cannot see through the tricks of the housing mafia, who successfully cheat her out of her fortune. Benedek Fliegauf's drama (Womb - Méh, 2010) is set in the future. Rebecca, the heroine, is unable to cope with the loss of her love, Thomas, so she offers to be impregnated with Thomas's DNA. This brings heavy social isolation, and fatal, unprocessed emotional burdens for both the woman and her son. Szandra, in Károly Makk's The Way You Are (Így, ahogy vagytok, 2010), finds new love, but she cannot stand idly 
by to watch the murder of his former protégé, so in revenge she publicly shoots the deputy mayor of the small town, making his future prospects even more doubtful in a morally depraved environment.

Another group of middle-class characters is trying to break free from their stagnant lives and stifling relationships, but the breakout does not always bring the hoped-for liberation; although in the meantime they get enriched with spiritual experiences and fateful realizations, the material and social decline is often irreversible. Emotions, as well as men, will play an important role in failure stories too. Stepping out of her seemingly ideal middle-class life, actress Juli, leaving her husband and daughter behind, seeks out a new self and moves in with the drugaddict András in Cloud Above the River Ganges (Felhô a Gangesz fölött, Gábor Dettre, 2001), whereupon the two go through the everyday hell of addiction. Later, despite being dragged back to reality by her husband, Juli ends up again, within a few weeks, next to András in hospital. The depressed and wealthy photo model, Csilla, in Paths of Light (A fény ösvényei, Attila Mispál, 2005) struggles alone in the world of superficial relationships and drug parties, until she suffers severe burns from a fatal encounter with a strange, homeless man. With permanent scars on her face, she needs to radically rethink her profession, family relationships and future. At first, the lonely heroine of Anarchists (Anarchisták, Tamás Tóth, 2000), Majka, bitterly discovers the signs of corruption in a charity organization, but her protests lead nowhere; together with Gavrilov, who is also about to rebel, they take revenge on corrupt leaders, but then their anarchist tendencies escalate: the boy gets hold of some weapons and eventually shoots Majka's anarchist father, too. Finally, they run away together. The young adolescent heroes of Who the Hell's Bonnie and Clyde? (Miskolci bonniésklájd, Krisztina Deák, 2005) and Girls (Lányok, Anna Faur, 2007) have no specific plans, they are drifting and take the first opportunity to break free, and are not worried about run-ins with the law. Lili flees with Pali from Miskolc, leaving behind her abusive stepfather, to undertake a bank robbery as a great life adventure; after their initial successes, the teenagers both end up in prison. In Faur's film, which is set in the nineties, the two teenage girls, Dini and Anita, have a home and family, yet they linger all day in Budapest; they get involved in minor thefts and learn to drive from taxi drivers, in exchange for favours. They dream of a trip to Switzerland, but end up killing a taxi driver to get the car they will need to go there - the police catch them almost immediately.

Emotions control the heroines of School of Senses (Érzékek iskolája, András Sólyom, 1996) and Stracciatella (Sztracsatella, András Kern, 1996), who stake their all on a single roll of the dice - and lose it when they fall in love. Lili Csokonai, 
the young gypsy girl, takes the first love of her life incredibly seriously, throwing herself into the relationship with extreme devotion; while she advances from a cleaning lady to a waitress, her attachment becomes more and more of a burden for the entrepreneur, who has a family. In a car accident after a quarrel between them, Lili loses her legs, and finds herself in a wheelchair in a panel apartment, under the care of a neighbouring man, Naxos; Lili finally takes revenge by shooting her successful and wealthy lover. In Kern's comedy, dr. Andrea Lantos and a middleaged orchestra conductor, recovering from a nervous breakdown, fall in love with each other whilst he is receiving psychological treatment. The family man does not dare stir things up because of his new love; when he breaks up with her, the psychiatrist is fired, so she has to return to her home village.

Only in two cases do we see that the heroines are free to decide how they want to go on with their lives, that they have real choices and their decision counts. Gyula Maár's film Whoops (Hoppá, 1993) presents the situation after the regime change from the perspective of a couple in their sixties who see themselves as losers of both systems. Ede wants to move to the countryside to keep the reminders of failure away from them, but Kati dreams of more and would prefer to actually leave her husband - yet returns to him at the end of the film. Aglaja, the title character of Krisztina Deák's adaptation (2012), has to follow the profession of her circus performer mother, but after the family's decline, she can only perform half-naked on the stages of cheap provincial variety shows. Under the pressure of her mother, she almost takes over from her the life-threatening and bizarre stunt of hanging by her hair; in the final scene, with a sudden bold decision, she cuts off her extended hair just before a major performance in Berlin - thus likely altering her fate.

\section{Financial Decline: from Above or Below}

In the Hungarian films after the regime change, financial collapse, like social decline, often affects characters who are already in poor financial conditions and struggling for survival, as well as suffering from loneliness; they slide further down, even if they had temporarily fought their way up before. In these mainly auteur drama films, individual efforts are made from time to time but always prove futile as the fate of the characters is decided by external occasional (misfortune) and lasting (difficulties) circumstances.

The struggle for emotional well-being and financial survival determines the everyday life of Sweet Emma's failing teachers, and this is echoed in the stories of the mother figures in Light-Sensitive Story (Fényérzékeny történet, Pál Erdőss, 1993) and 
Fresh Air (Friss levegó, Ágnes Kocsis, 2006). Juli, the protagonist of Erdőss's film, is a divorced photographer in her thirties who lives with her university student lover and young son. Financial problems make the love relationship even worse, but Juli breaks down only when she realizes that she has lost her son, who was sent abroad to her exhusband. Juli converts everything she has into money in order to go after him, but she never gets back her son. In Ágnes Kocsis's film, the neat-freak Viola, who is raising her adolescent daughter alone, is attacked and robbed at her workplace, in a public toilet. While she is hospitalized, her daughter reluctantly steps into her position, but the ending leaves open as to whether Viola will ultimately retain her job or not. Anna apparently has no say in her fate in The Days of Desire (A vágyakozás napjai, Pacskovszky József, 2009). As a young girl she does housework for a wealthy couple who are living a self-destructive life. In an unexpected development of equilibrium the mute girl seems to find not only a home but also a family: the employers see in her their daughter, who they had previously tragically lost. But the apparent happiness disintegrates from one moment to the next: Anna is left without relationships, work, accommodation and money when she is suddenly dismissed; her suitor also breaks up with her after realizing that she is not the daughter of the rich family. While Anna's story is about unfortunate circumstances, Lili of The School of Senses, or the teenage girls of Bloodline, slide even further down from their original position of having nothing. The young girls take revenge for their emotional loss through murders, and are pushed into the realm of lawlessness and moral decline by a combination of circumstances and bad decisions. Protagonists of crime films Who the Hell's Bonnie and Clyde? and The Great Post Office Robbery (A nagy postarablás, Sándor Sőth, 1992), and the comedy Gulls and Gangsters (Balekok és banditák, Péter Bacsó, 1996) are also law-breakers, but their crimes are portrayed in a different tone. In Sőth's crime comedy, a small, pitiful team of a father and son come up with the big idea, together with the lover, Mari, who is also an accomplice: they start operating the local post office before its official opening to benefit their own pockets, but the profits of the trickery are eventually stolen by their even more devious acquaintances. In Bacsó's satire, Piroska becomes the girlfriend of a successful criminal who starts out as a stooge and then gets involved in increasingly dirty affairs, until the woman finally gets tired of lying and leaves him.

Only in a few exceptional cases does financial decline affect higher social class heroines who are living in better material conditions. While the protagonist of The Eighth Day of the Week loses her house and garden due to her inattention and credulity, in the grotesque comedy Sexplorers (Szüzijáték, István Nyíri Kovács, 2006), the young girl, Anna enlists the services of a company to lose her innocence, even 
though the right partner (in the form of her shy tenant) has been there in her apartment all along. Anna loses all her belongings on account of the horrible Virgin Ltd., but the love found compensates for everything. The aging, well-to-do title character in the 1930s-set story of Eszter's Inheritance (Eszter hagyatéka, József Sipos, 2008), a drama adapted from Sándor Márai's novel, also does not mind losing everything for her love: meeting the man after twenty years, she moves voluntarily into a nursing home and gives up her property for the benefit of her former lover and his adult children.

\section{Conclusions}

The political transition following the collapse of communism radically altered the economic and social structure of Hungarian society. The growing unemployment, the inequalities in income and property, the narrowing and consolidating upper classes and the lagging lower classes led to increasing differences in living standards and the deterioration of living conditions for many. The social experiences of losses and failures and the closing social structure are reflected directly and explicitly in many Hungarian films made between 1990 and 2015. The database created by our research allowed us to group and review the films that show mobility processes featuring women. Female heroines in these films appear to move up the slope, but are pulled down not only by the gravitational force of economic and social crises, but also by the lack of emancipation and lack of gender equality.

By exploring the attributional framework (Weiner 2011) of the films, with consideration for the way the narratives present female characters' skills and prospects in relation to the external circumstances, I proposed a way to explain how contemporary Hungarian film imagines mobility opportunities for women in the society of regime change. Based on this, it became apparent that according to these movies, personal, internal disposition is not enough to enable financial success or social ascension, while downward movements are accelerated by the overwhelming power of permanent situational, external factors - namely the social and economic environment. That is, in the context of multiple pressures and subordination, women rarely achieve success because of their own qualities, skills or perseverance; stories emphasize the weight of external conditions, in the form of luck, relationships, men, and economic circumstances.

The research also highlighted the polarization of the mobility stories from a genre perspective, meaning that upward mobility is regularly represented by genre films, while downward mobility is the preserve of auteur films. Stories of female financial success, for example, are typically and exclusively told by genre films (comedies, 
dramas, crime films), which acknowledge individual characteristics (effort, talent) of women, but also accentuate the role of patrons and luck. Getting rich or achieving a better material position in these films is not an everyday, normal practice, rather it is an exception, and it is not related to hard work, employment, or being an expert at something. By featuring luck, rewards, prizes and inheritance instead of salary or income, these films express a pessimistic and critical view of the value of work and the legal opportunities of making money in the society after the regime change. Social ascension of women, presented in dramas and comedies, sometimes accompanies financial success, but is often attained through marital mobility, or promotion through partnerships, thus completely eliminating the role of women's individual competencies, and suggesting the survival of a traditional gender hierarchy.

The research also explored the female social decline stories, which make up the overwhelming majority - appearing typically in auteur films, and sometimes in the drama, melodrama and comedy genre films. These usually emphasize the influential power of external causes and hopeless circumstances, while women's relationships with men also play a crucial role in impoverishment and decline processes. Failure stories often report the fall of heroines living on the social periphery, who often slide even further from their initial low position, indicating the structural constraints of this social layer and the one-way mobility at this level. Also preferred by auteur films (and sometimes drama, melodrama, but rarely crime and comedy genre films), the financial collapse of women, like social decline, usually affects characters who are already in poor financial conditions and struggling for survival, and also suffering from loneliness; they slide further, even if they had managed to climb higher before. The visibility of women in Hungarian film after the regime change may have been transformed, but their mobility opportunities still report a traditional gender hierarchy, and a difficult, downward sloping social terrain.

\section{References}

Andorka, Rudolf. 2006. Bevezetés a szociológiába [Introduction to Sociology]. Budapest: Osiris.

Bukodi, Erzsébet. 2002. Társadalmi mobilitás Magyarországon, 1983-2000 [Social Mobility in Hungary, 1983-2000]. In Társadalmi riport 2002 [Social Reportage 2002], eds. Kolosi Tamás, Tóth István György and Vukovich György, 193-206. Budapest: TÁRKI.

Csepeli, György. 1997. Szociálpszichológia [Social Psychology]. Budapest: Osiris Kiadó. 
Gyarmati, Gyöngyi. 2004. Nők, játékfilmek, hatalom [Women, Feature Films, Power]. In Az 1950-es évek Magyarországa játékfilmeken [Hungary in the 1950s in Feature Films], eds. Gyarmati Gyöngyi, Schadt Mária and Vonyó József, 26-40. Pécs: Asoka Bt.

Havas, Júlia Éva. 2010. Magyar romantikus vígjáték a 2000-es években [Hungarian Romantic Comedies in the 2000s]. Metropolis vol. 14, no. 1: 66-78.

Havas, Júlia Éva. 2011. Test-tanok. Kortárs magyar szerzői filmek nőképe [BodyTenets. The Image of Woman in Contemporary Hungarian Auteur Films]. Metropolis vol. 15, no. 3: 30-41.

Hock, Bea. 2007. Hídemberné, aki maga hidat nem épít. A magyar mozi esete a nőkkel az utóbbi 60 évben [Mrs. Bridgeman Who does not Build a Bridge Herself. The Case of Hungarian Cinema with Women in the Last 60 Years]. Eszmélet vol. 19, no. 73: 81-101.

Hock, Beata. 2010. Sites of Undoing Gender Hierarchies: Woman and/in Hungarian Cinema (Industry). Media Research: Croatian Journal for Journalism and Media vol. 16, no. 1: 9-30.

Hollós, Laura. 2000. Nőfilmek - nemcsak nőknek [Women’s Films - Not Just for Women]. Metropolis vol. 4, no. 4: 69-86.

Huszár, Ákos and Záhonyi Márta. 2018. A szubjektív mobilitás változása Magyarországon [Changes of Subjective Mobility in Hungary]. Demográfia vol. 61, no. 1: 5-27.

Király, Hajnal. 2018. A női és etnikai identitás performanciái a kortárs magyar filmben [Performances of Female and Ethnic Identity in Contemporary Hungarian Film]. In Nemek és etnikumok terei a magyar filmben [Spaces of Gender and Ethnicity in Hungarian Film], eds. Győri Zsolt and Kalmár György, 59-69. Debrecen: Debreceni Egyetemi Kiadó.

Lakatos, Gabriella. 2018. „Aki dolgozik, az nem ér rá pénzt keresni.” Sikernarratívák a magyar vígjátékokban 1931 és 1944 között. [“Those Who Work Have No Time to Earn Money." Success Narratives in Hungarian Comedies between 1931 and 1944]. Metropolis vol. 22, no. 3: 10-23.

Németh, Renáta. 2006. A társadalmi mobilitás változásai Magyarországon a rendszerváltás folyamán [Changes in Social Mobility in Hungary during the Change of Regime]. Szociológiai Szemle no. 4: 19-35.

Margitházi, Beja. 2019. Rendszerváltás? A kortárs magyar film nóképéről [Change of Regime? Women of Post-Transitional Hungarian Cinema]. Korunk vol. 30, no. 6: 13-21. 
Róbert, Péter. 1999. Társadalmi mobilitás és rendszerváltás [Social Mobility and Regime Change]. Századvég no. 15: 73-86.

Róbert, Péter and Bukodi Erzsébet. 2004. Changes in Intergenerational Class Mobility in Hungary, 1973-2000. In Social Mobility in Europe, ed. Richard Breen, 287-314. Oxford: Oxford University Press.

Schadt, Mária. 2012. Ideológia és valóság: Az 1950-es évek nőideáljai a magyar filmekben [Ideology and Reality: Female Ideals of the 1950s in Hungarian Films]. Kultúra és közösség vol. 3, no. 1-2: 109-120.

Szilágyi, Erzsébet. 1983. A nók otthon és a munkahelyen: az 1970-es évtized magyar filmjeinek nóképe és ennek közönségfogadtatása [Women at Home and at Work: The Image of Women in Hungarian Films of the 1970s and Their Reception]. Budapest: Tömegkommunikációs Kutatóközpont.

Szilágyi, Erzsébet. 1985. Nők az 1970-es és az 1980-as évtized magyar filmjében [Women in the Hungarian films of the 1970s and 1980s]. Filmkultúra vol. 21, no. 8: 24-37.

Thumim, Janet. 1992. Celluloid Sisters: Women and Popular Cinema. New York: Palgrave Macmillan.

Valuch, Tibor. 2015. A jelenkori magyar társadalom [Contemporary Hungarian Society]. Budapest: Osiris.

Vajdovich, Györgyi. 2016. Szende titkárnők, kacér milliomoslányok. Az 1931-1945 közötti magyar vígjátékok nőképe [Modest Secretaries, Coquette Millionaire Girls. Representation of Female Figures in Hungarian Comedies between 1931 and 1945]. Metropolis vol. 20, no. 4: 8-23.

Vajdovich, Györgyi. 2019. Jó feleség vagy emancipált, dolgozó nő? Nőszerepek és női mobilitás az 1931-44 közötti magyar filmben [Good Wives, or Emancipated, Working Women? Female Roles and Female Mobility in Hungarian Films between 1931 and 1944]. Metropolis vol. 23, no. 4: 8-29.

Varga, Balázs. 2016. Többszörös szorításban. Maszkulinitáskoncepciók kortárs magyar romantikus vígjátékokban [Multiple Expectations. Concepts of Masculinities in Contemporary Hungarian Romantic Comedies]. Metropolis vol. 20, no. 4: 40-57.

Varga, Éva and Kresalek Gábor. 1995. Nők az ötvenes évek filmjeiben [Women in the Movies of the 1950s]. In Vera (nem csak) a városban: tanulmányok a 65 éves Bácskai Vera tiszteletére [Vera (not only) in the City: Studies in Honor of 65-yearold Vera Bácskai], ed. Á. Varga László, 361-378. Budapest: Hajnal István Kör Társadalomtörténeti Egyesület. 
Virginás, Andrea, Bíró Emese, Botházi Mária and Kassay Réka. 2018. Kollektív emlékeink a mobilitásról. A női alakoktól a női alkotókig magyar gyártási kontextusban [Our Collective Memories of Mobility. From Female Figures to Female Creators in the Context of Hungarian Film Production]. In Nemek és etnikumok terei a magyar filmben [Spaces of Gender and Ethnicity in Hungarian Film], eds. Győri Zsolt and Kalmár György, 45-58. Debrecen: Debreceni Egyetemi Kiadó.

Weiner, Bernard. 2011. An Attribution Theory of Motivation. In Handbook of Theories of Social Psychology. Volume One, eds. Paul A. M. Van Lange, Arie W. Kruglanski and Tory E. Higgins, 135-155. London: SAGE Publications.

\section{List of Figures}

Figure 1. Distribution of male protagonists according to social strata (number/per year).

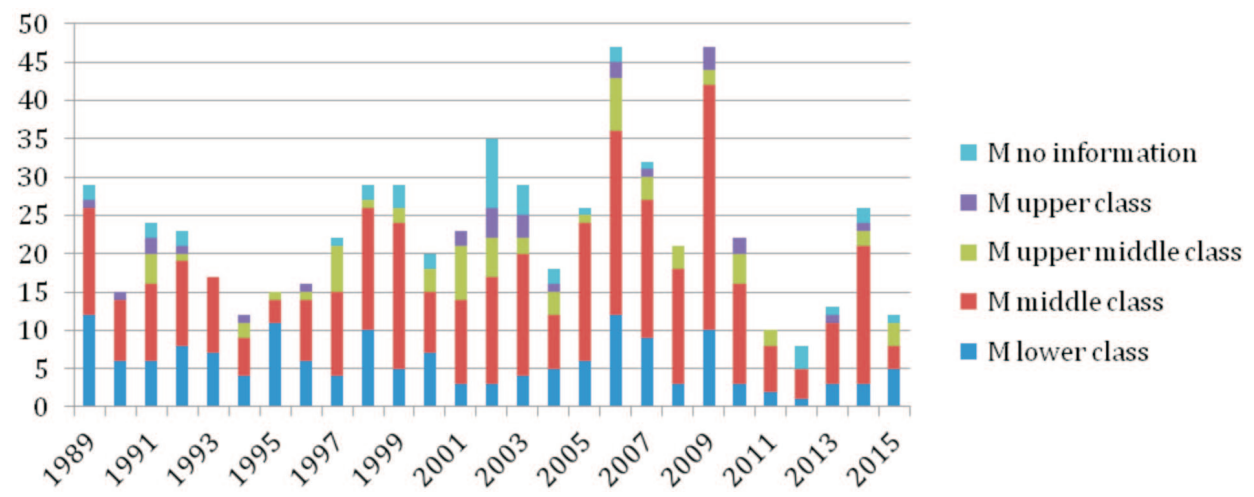

Figure 2. Distribution of female protagonists according to social strata (number/per year).

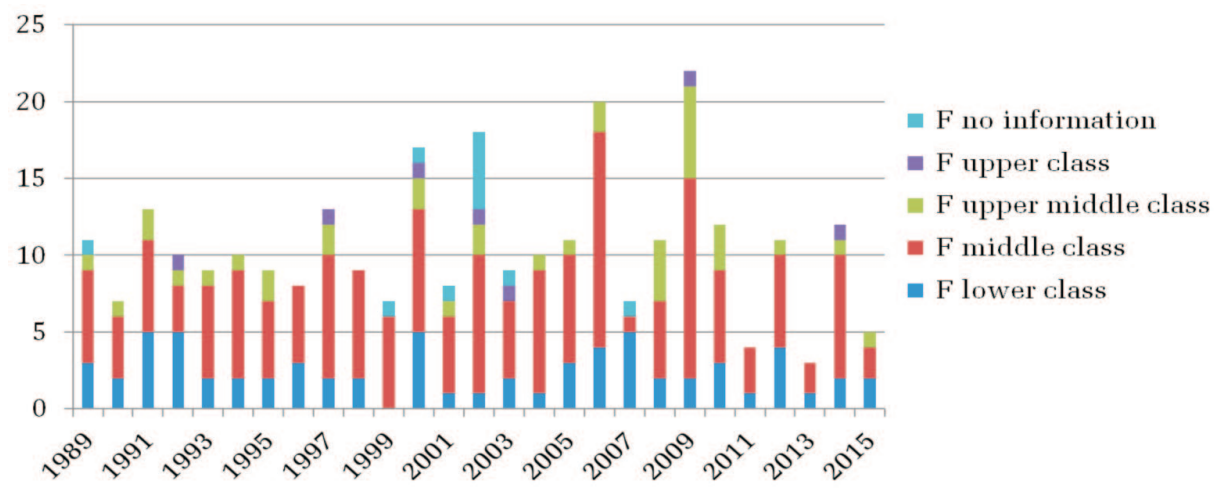


Figure 3. Distribution of male protagonists according to financial position (number/ per year).

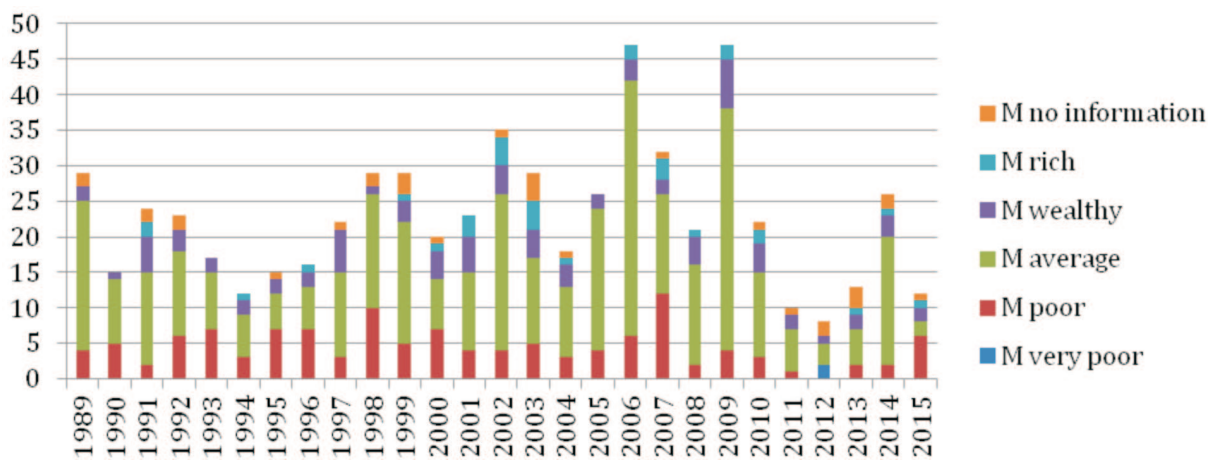

Figure 4. Distribution of female protagonists according to financial position (number/per year).
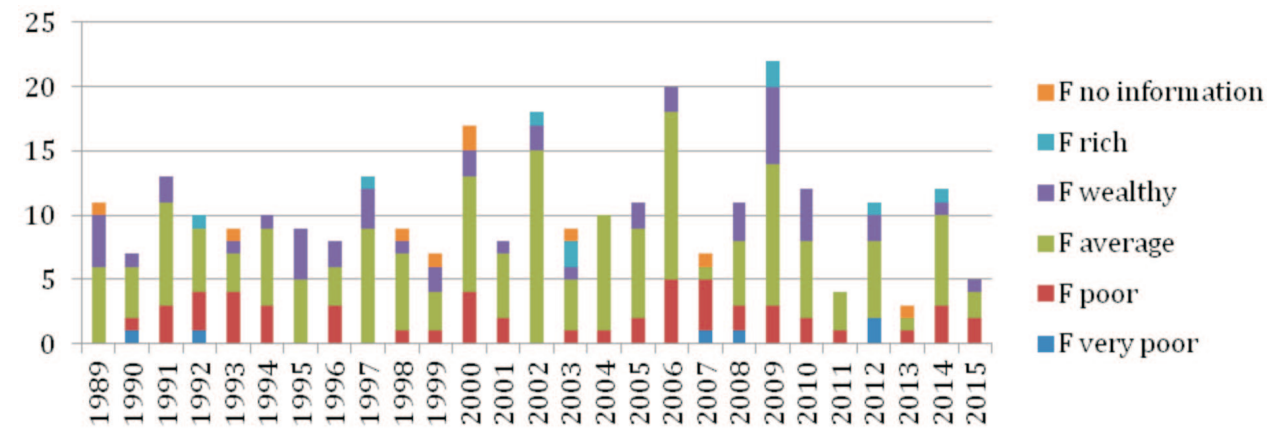

Figure 5. Social and financial mobility of male protagonists (percentage of male protagonists per year).
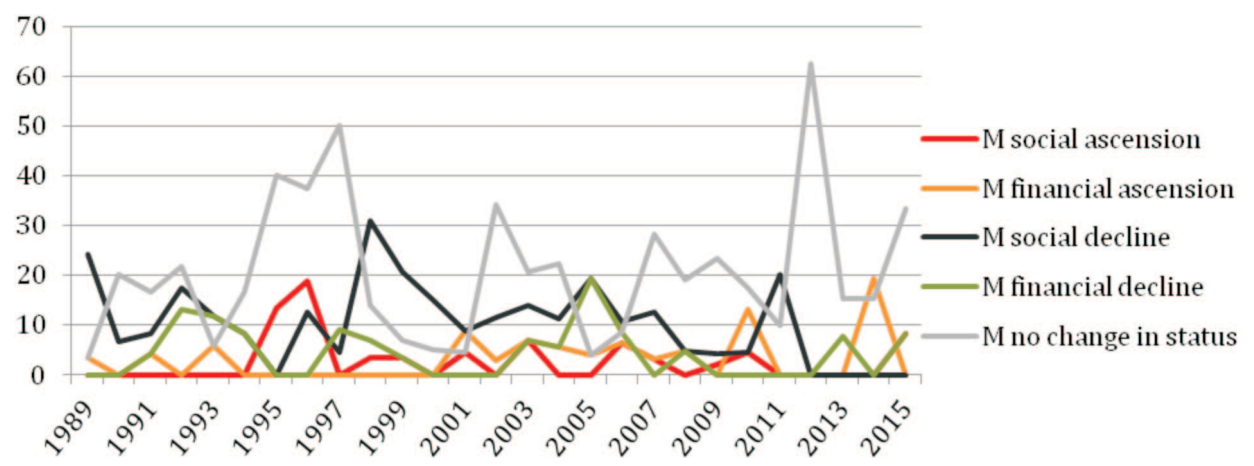
Figure 6. Social and financial mobility of female protagonists (percentage of female protagonists per year).

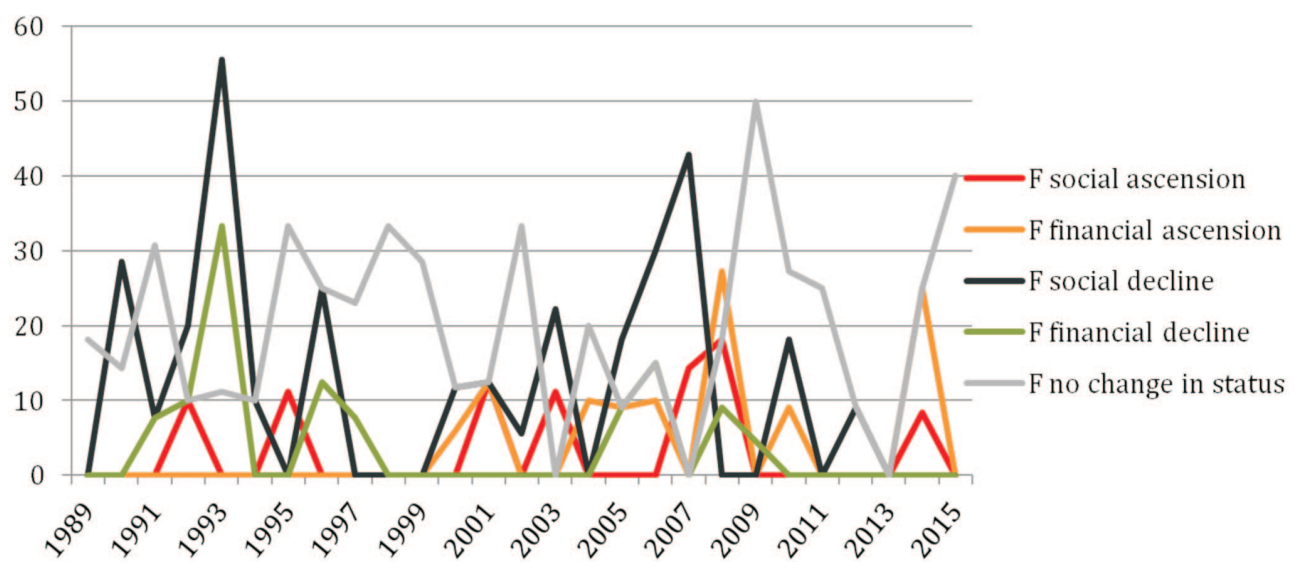

Figure 7. Social and financial mobility of female and male protagonists between 1964-1989 and 1990-2015 (percentage).

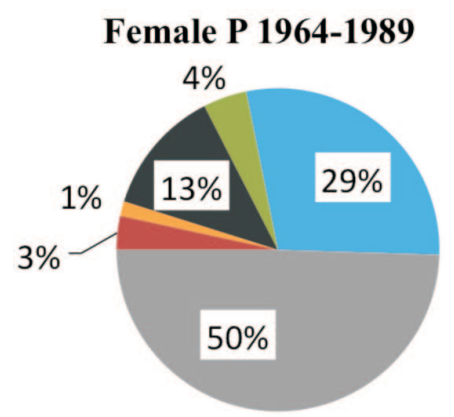

Female P 1990-2015

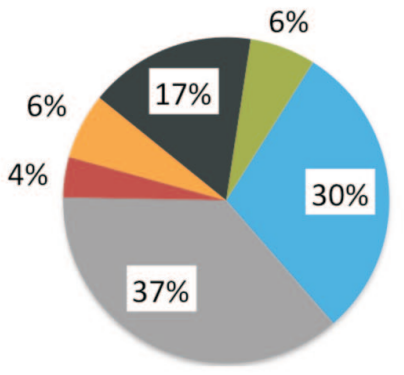

Male P 1964-1989

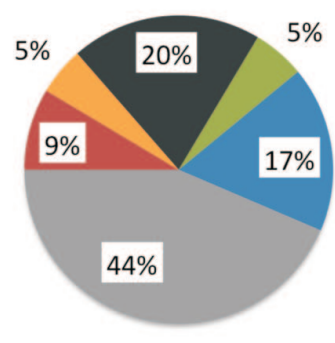

Male P 1990-2015

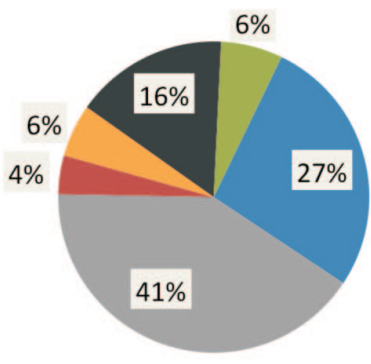


Figure 8. Distribution of mobility values of female protagonists between genre and auteur films (by the number of films).

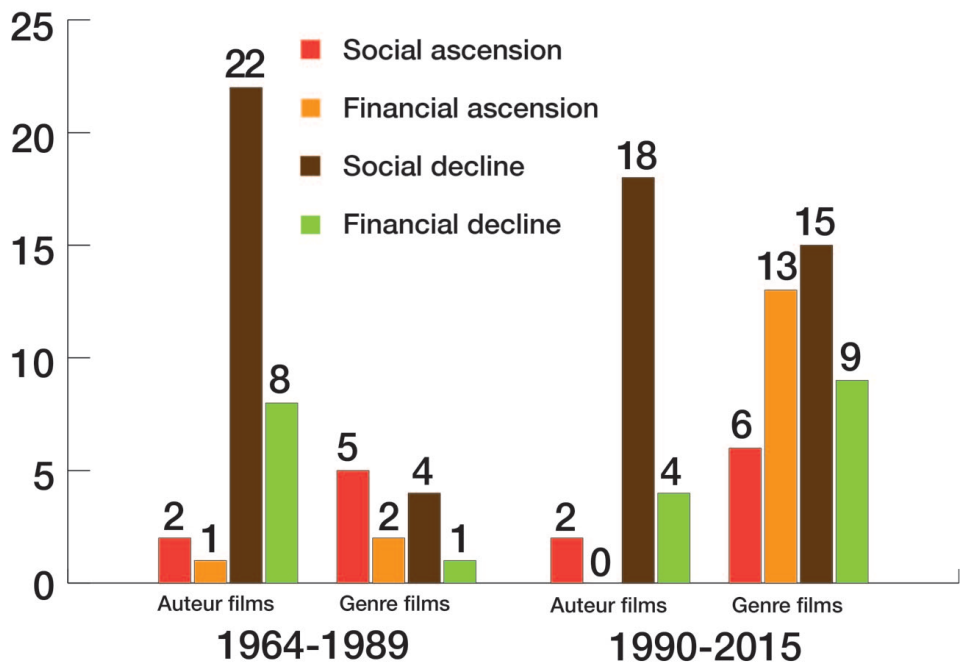

Figure 9. Causes associated with individual successes or failures classified based on Bernard Weiner's attribution model.

\begin{tabular}{lll}
\hline & $\begin{array}{l}\text { permanent, long-term } \\
\text { (stable) }\end{array}$ & $\begin{array}{l}\text { occasional, temporary } \\
\text { (unstable) }\end{array}$ \\
\hline $\begin{array}{l}\text { Disposition } \\
\text { (personal, internal) }\end{array}$ & $\begin{array}{l}\text { ability, } \\
\text { skill, } \\
\text { talent }\end{array}$ & $\begin{array}{l}\text { effort, } \\
\text { motivation, } \\
\text { mood }\end{array}$ \\
\hline Situation & task difficulty, & $\begin{array}{l}\text { help, } \\
\text { (external, circumstances) } \\
\text { origin (gender, class, etc.), } \\
\text { other economic and social } \\
\text { factors }\end{array}$ \\
\hline
\end{tabular}

